

\section{Editorial Board of the Working Papers}

Martin Summer, Coordinating Editor

Ernest Gnan,

Günther Thonabauer

Peter Mooslechner

Doris Ritzberger-Gruenwald

\section{Statement of Purpose}

The Working Paper series of the Oesterreichische Nationalbank is designed to disseminate and to provide a platform for discussion of either work of the staff of the OeNB economists or outside contributors on topics which are of special interest to the OeNB. To ensure the high quality of their content, the contributions are subjected to an international refereeing process. The opinions are strictly those of the authors and do in no way commit the OeNB.

Imprint: Responsibility according to Austrian media law: Günther Thonabauer, Secretariat of the Board of Executive Directors, Oesterreichische Nationalbank Published and printed by Oesterreichische Nationalbank, Wien. The Working Papers are also available on our website (http://www.oenb.at) and they are indexed in RePEc (http://repec.org/). 


\section{Editorial}

On the occasion of the 65th birthday of Governor Klaus Liebscher and in recognition of his commitment to Austria's participation in European monetary union and to the cause of European integration, the Oesterreichische Nationalbank (OeNB) established a "Klaus Liebscher Award". It will be offered annually as of 2005 for up to two excellent scientific papers on European monetary union and European integration issues. The authors must be less than 35 years old and be citizens from EU member or EU candidate countries. The "Klaus Liebscher Award" is worth EUR 10,000 each. The winning papers of the forth Award 2008 were written by Kerstin Gerling and by Aleksandra Riedl and Silvia Rocha-Akis (shared award). Kerstin Gerling's paper was presented in Working Paper 141, while the second contribution is contained in this Working Paper.

In this paper Aleksandra Riedl and Silvia Rocha-Akis test one of the fundamental assumptions in the tax competition literature, namely, that a country's taxable income depends on the tax policies pursued in the domestic and in neighbouring countries. Based on a panel of annual data of 14 Western European countries spanning the period 1982 to 2004 the authors show that the common trend in falling corporate income tax (CIT) rates can in part be explained by the existence of fiscal externalities in the form of international resource flows. The results confirm the presumption put forward in recent empirical tax reaction function studies, that interdependent tax setting behaviour is evidence of tax competition. However, taxable corporate income is shown to react inelastically to domestic and to foreign tax rates. Thus, the authors claim that the observed rise in CIT revenues in Europe between 1982 and 2004 cannot be explained by the trend in falling CIT rates. Moreover, they find that large countries' tax bases are more responsive to neighbouring countries' tax policies, which is in contrast to the classic asymmetric tax competition literature. 



\title{
Testing the tax competition theory: How elastic are national tax bases in Western Europe?*
}

\author{
Aleksandra Riedl ${ }^{\dagger}$ and Silvia Rocha-Akis ${ }^{\ddagger}$
}

March 31, 2008

\begin{abstract}
In this paper, we test one of the fundamental assumptions in the tax competition literature, namely, that a country's taxable income depends on the tax policies pursued in the domestic and in neighbouring countries. Based on a panel of annual data of 14 Western European countries spanning the period 1982 to 2004, we show that the common trend in falling corporate income tax (CIT) rates can in part be explained by the existence of fiscal externalities in the form of international resource flows. Our results confirm the presumption put forward in recent empirical tax reaction function studies, that interdependent tax setting behaviour is evidence of tax competition. However, taxable corporate income is shown to react inelastically to domestic and to foreign tax rates. Thus, the observed rise in CIT revenues in Europe between 1982 and 2004 cannot be explained by the trend in falling CIT rates. Moreover, we find that large countries' tax bases are more responsive to neighbouring countries' tax policies, which is in contrast to the classic asymmetric tax competition literature.
\end{abstract}

Keywords: tax competition, corporate income tax base elasticity, asymmetric countries, instrumental variables, spatial econometrics JEL classification: H71, H72, H77, H87, C21, C23

\footnotetext{
*We thank Markus Leibrecht, Ana B. Ania, Christian Bellak, Manfred M. Fischer, Andreas Wagener and Christine Zulehner for helpful comments. We also gratefully acknowledge the financial support from the Austrian Science Fund for the subprojects SFB 112003 and 112008 headed by Ingrid Kubin and Martin Zagler.

${ }^{\dagger}$ Institute for Economic Geography and GIScience, Vienna University of Economics and Business Administration, UZA 4, room A 414, Nordbergstraße 15, 1090 Vienna, Austria. Tel: +43 131336 / 4846, Fax:+43 131336 703, E-Mail: aleksandra.riedl@wu-wien.ac.at

$\ddagger$ Department of Economics, Vienna University of Economics and Business Administration, UZA 4, room D 311, Nordbergstraße 15, 1090 Vienna, Austria. Tel.:+43 131336 / 5855, Fax:+43131336 905855, E-Mail: silvia.rocha@wu-wien.ac.at
} 


\section{Introduction}

The strengthening of economic linkages at international level has sparked interest in the study of strategic interactions among countries. A rapidly growing empirical literature draws on spatial econometric modeling techniques designed to tackle the estimation of interdependence across space. One manifestation of such interdependence can be found in the realm of public finance. Based upon the early theoretical models of Zodrow and Mieszkowski (1986) and Wilson (1986) it has been recognised that national authorities are increasingly affected by policy measures in neighbouring countries. The rise in international investment opportunities and the growing role of multinational corporations and their tax planning have placed the spotlight on corporate income taxation as a strategic instrument used by policymakers to attract mobile capital investments made by firms. Theoretical models on strategic tax competition predict that countries cut tax rates on mobile tax bases in an attempt to keep up with lower tax competing countries in order to avoid an outflow of taxable income. Yet, empirical evidence of tax base elasticities with respect to neighbouring countries' tax rates is so far missing.
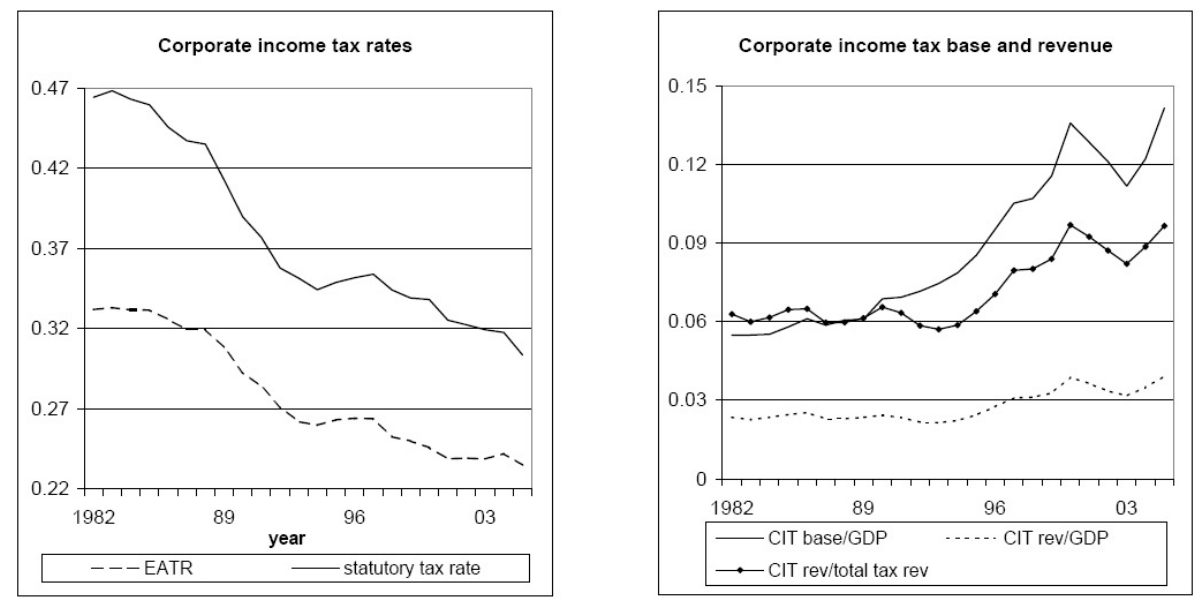

Figure 1: Average corporate income tax (CIT) rates, base and revenue (rev) in Europe, 1982 - 2005. Source: See table 7 in appendix A.2.

The left plot of figure 1 shows that average corporate profit tax rates have declined sharply in Western Europe since 1982. ${ }^{1}$ From an average rate of $46 \%$ in 1982, the statutory CIT rate fell to $30 \%$ in 2005 . The effective average corporate tax rate (EATR) has experienced a slightly less pronounced fall which can be

\footnotetext{
${ }^{1}$ The European countries under consideration are Austria (AT), Belgium (BE), Switzerland (CH), Germany (DE), Spain (ES), Finland (FI), France (FR), Greece (GR), Ireland (IE), Italy (IT), Netherlands (NL), Norway (NO), Portugal (PT), Sweden (SE) and the United Kingdom (UK).
} 
explained by the fact that in several countries the lowering of the statutory tax rate was accompanied by a simultaneous reduction of depreciation allowances (see Devereux et al. (2002b)).

This observed novel trend could reflect a tendency for governments to respond more intensely to neighbouring countries' CIT policies. Indeed, Devereux et al. (2002a), Altshuler and Goodspeed (2002) and Redoano (2007) find a strong interdependence among governments' CIT policies where the former two investigate OECD countries and the latter focuses on European Union (EU) countries. What these studies have in common is that they estimate a reaction function which shows how the tax rate in a given country depends on the tax rates in other countries. Despite the general consensus among these authors that Nash reaction functions are positively sloped and that the estimated parameter of interdependence is significant, Brueckner (2003) rightly points out that "reliable estimates of reaction-function parameters [...] do not directly reveal the nature of the behavior underlying the observed interaction". ${ }^{2}$ In particular, it is not clear whether the driving force of this trend in tax rates is a consequence of tax competition or whether tax mimicking behaviour, motivated by yardstick competition, is at the heart of this development. ${ }^{3}$ As Brueckner (2003) demonstrates, a nonzero slope for a tax reaction function could reflect either of these processes. ${ }^{4}$ In order to show that the spatial correlation between tax rates is driven by tax competition, evidence on the responsiveness of a country's capital stock to neighbouring countries' tax rates is needed.

This is precisely the aim of this paper. Since only a part of the capital stock is subject to domestic corporate income taxation, in this study we shall focus on the variability of the CIT base. If governments' budgets are indeed affected by each others' taxes on mobile resources, we should find that the domestic tax base is negatively affected by the domestic tax rate and positively affected by neighbouring countries' tax rates. Based on a panel of annual data of 14 western European countries spanning the period 1982 to 2004, we present empirical evidence on the magnitude of fiscal externalities. At the municipal level, Brett and Pinkse (2000), Buettner (2003) and Brett and Tardif (2007) have undertaken similar investigations. While Buettner (2003) finds that solely the tax bases of relatively small municipalities in a German state are positively affected by neighbouring local jurisdictions' business tax rates, the other two studies cannot confirm such effects in Canadian provinces.

\footnotetext{
${ }^{2}$ Griffith and Klemm (2004) and Revelli (2005) also discuss this issue.

${ }^{3}$ According to the yardstick competition theory, suggested by Besley and Case (1995), voters in a given jurisdiction evaluate the performance of their government by using other governments' performances as a yardstick. To the extent that the electorate is informed about other jurisdictions' policies, the probability of reelection of a government depends on its own and the other governments' decisions. If politicians perceive the performance comparison by voters as an important determinant for the voting outcome, the model predicts that national authorities engage in mimicking each others' policies.

${ }^{4}$ Moreover, it should be noted that, even in the absence of strategic behaviour, one can obtain a significant spatial correlation parameter if the econometric model specification does not account for the exogenous correlation in country-specific characteristics and common shocks affecting spatially related countries.
} 
In our view, the empirical analysis of tax competition at international level is especially relevant given the impressive heterogeneity in the taxation of mobile tax bases ${ }^{5}$ and the potential distortions caused by fiscal externalities. Besides domestically determined tax base effects there are several channels by which international CIT rate differentials could provoke fiscal externalities. The economic literature mainly discusses three forms of international tax base mobility, namely, foreign direct investment (FDI), foreign portfolio investment, and profit shifting. ${ }^{6}$ In contrast to previous studies, we do not analyse a particular channel through which revenue might leak away following a tax rate increase. Instead, we take a macro-economic perspective, focusing on the impact of corporate income taxation on the aggregate domestic level of taxable profits. Such an approach implicitly takes into account that not all companies have the opportunity to engage in international activities intended to circumvent higher taxes. At the political level, the observation that the tax burden is gradually shifted from mobile towards less mobile tax bases, such as labour, frequently leads to debates on the welfare implications of changes in national European tax structures. To the extent that, under rigid labour markets, higher labour taxes and social security contributions translate into higher labour costs, such developments are likely to have a dampening effect on employment and growth. ${ }^{7}$ Accordingly, efforts aimed at coordinating national tax systems have long been on the political agenda of the EU.

Although the focus in empirical tax competition research is generally placed on statutory tax rates, a crucial economic variable is the change in tax revenues raised from corporate income. The theory of tax competition predicts that countries mutually undercut each others' tax rates, leading to an equilibrium with too low tax rates and too low tax revenues, and thus an underprovision of public services. At first sight, the theory seems to contradict reality. In particular, the drop in CIT rates has not been reflected by a drop in the revenues from corporate profit taxation. The right plot of figure 1 shows that between 1982 and 2005 the CIT revenues rose by $67 \%$ as a share of GDP and by $54 \%$ as a share of total tax revenues. Obviously, tax receipts depend not only on the level of tax rates, but also on the level of taxable reported income. As shown in the same plot, the average CIT base, given by the ratio of CIT revenues and the CIT rate, increased by $158 \%$ as a proportion of GDP. ${ }^{8}$ Faced with such data, one could conclude that there is a negative relation between tax rates and revenues, i.e., that the tax base is elastic with respect to taxes. Such a result would lend support to the claim that tax competition is welfare-improving.

While GDP-weighted tax revenues in the period 1982 to 2005 have increased in nearly all countries, ${ }^{9}$ it is interesting to note that the rise in taxable prof-

\footnotetext{
${ }^{5}$ See Devereux (2007).

${ }^{6}$ See, for instance, Hines (1999), Desai and Dharmapala (2007) and Clausing (2003) for empirical analyses on each of these flows, respectively.

${ }^{7}$ Rodrick (1997), Daveri and Tabellini (2000), and Faggio and Nickell (2007) are among the studies that investigate the link between labour taxation and employment.

${ }^{8}$ For a detailed discussion of the corporate income tax base measure, refer to section 3.3.

${ }^{9}$ Over the observed time period, the CIT revenue as a share of GDP has not risen in
} 
its as well as the trend in tax revenues have been disproportionate regarding the country size distribution. Specifically, the GDP-weighted CIT base has increased more than twice as much in small than in large countries, i.e. $214 \%$ versus $63 \%$ whereas the statutory tax rate on average fell by $41 \%$ in small and by $26 \%$ in large countries (see figure 2 ). ${ }^{10}$
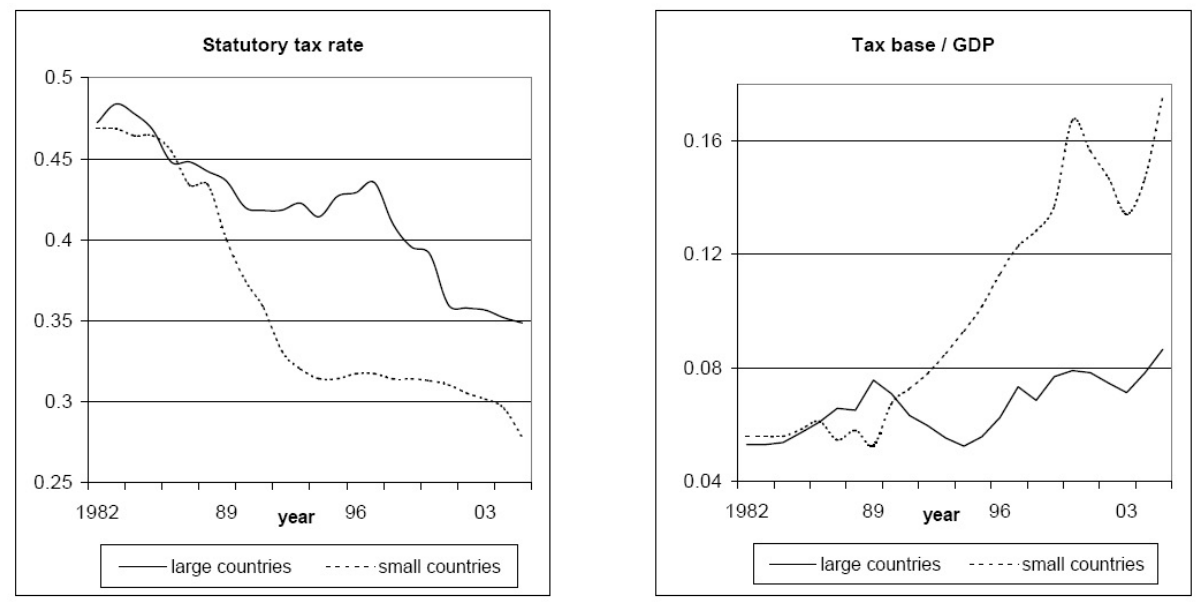

Figure 2: Comparison of average corporate income tax rates and bases in small and in large European countries, 1982-2005. The country categorisation by size is discussed in section 4 . Source: See table 7 in appendix A.2.

Against this background, we test the often cited finding of Bucovetsky (1991) and Wilson (1991) whereby a small country faces a more elastic tax base so that it optimally undercuts the larger country's tax rate. In equilibrium the small country is predicted to gain while the large country is predicted to lose from tax competition.

A major finding is that a country's CIT base is positively and significantly affected by the CIT rate of its neighbours. Clearly the results confirm that the observed tax rate interdependence in Europe, measured in the form of tax reaction functions in recent empirical papers, can in part be explained by the existence of fiscal externalities as stated in the classic tax competition literature. We can therefore reject the hypothesis that the tax reduction trend is unrelated to international tax competition for mobile resources.

While being aware of the shortcoming associated with viewing the taxation of corporate income in isolation, the finding that the tax base reacts inelastically to the domestic and to foreign countries' tax rates suggests that the observed

Germany, Italy and the UK. Measured in proportion to total tax revenues, corporate revenues failed to rise in Italy and the UK and rose only by $2 \%$ in Germany.

${ }^{10}$ The discrepancy between small and large countries is even more pronounced regarding the development of CIT revenues as a share of GDP which increased by $93 \%$ and $26 \%$ in small and large countries, respectively. 
rise in CIT revenues in Europe between 1982 and 2004 cannot be explained by the trend in falling CIT rates. The picture is sharpened if we control for country size. In accordance with the theoretical predictions in the asymmetric tax competition literature, we find that, compared to large countries, small countries exhibit a significantly higher tax base elasticity with respect to the own tax rate. Yet, the same does not apply when it comes to the cross tax elasticity. We find that large countries' tax bases are more sensitive to foreign tax policies which explains why countries such as Germany and France are more supportive of tax coordination efforts.

In the following section we review the theoretical background required to derive the tax base elasticities in the symmetric and the asymmetric tax competition framework. We then present the econometric model and discuss relevant estimation issues. Finally, section 5 reports the results and section 6 concludes with some policy implications of our results.

\section{Theoretical background}

Since the primary purpose of this study consists of empirically identifying the presence and magnitude of horizontal fiscal externalities predicted by the classic tax competition theory (e.g. Zodrow and Mieszkowski (1986)), we restrict ourselves to reviewing only those aspects of the underlying theory that are directly of relevance to us. That is, we focus on the impact of tax policy on an internationally mobile tax base. The standard model describes a situation in which small, symmetric countries compete for capital by setting their tax rates in a strategic fashion. In each country, competitive firms produce a homogeneous good using as inputs labour and capital where labour is inelastically supplied and internationally immobile. The production function, $f\left(k_{i}\right)$, in each country $i=1, \ldots, N$, possesses the usual properties $f^{\prime}\left(k_{i}\right)>0$ and $f^{\prime \prime}\left(k_{i}\right)<0$ where $k_{i}$ denotes the amount of capital-labour ratio employed in country $i$. The output is partly intended for private consumption and partly transformed into a public good. Denoting each country $i$ 's share of the world population by $s_{i}$, $\sum_{i}^{N} s_{i}=1$, and the world capital-labour ratio by $k^{*}$, the world capital market clearing condition implies $k^{*}=\sum_{i}^{N} s_{i} k_{i}$. Due to symmetry, $k^{*}$ corresponds to the capital-labour endowment in each country, $k_{i}$. The government in country $i$ levies a $\operatorname{tax} \tau_{i}$ on the capital employed within its jurisdiction in order to finance the public good. A central assumption in tax competition models is that capital is mobile across jurisdictions. In effect, perfect capital mobility implies that there is one world capital market. Due to profit maximisation, the marginal product of capital equals its marginal cost, $\tau_{i}+\rho$, where $\rho$ is the interest rate which is equalised across countries due to investors' arbitrage behaviour, so that in equilibrium

$$
f^{\prime}\left(k_{i}\right)-\tau_{i}=\rho \quad \forall i
$$

Since the supplies of labour and capital are exogenous, differences in the marginal productivity of capital can only stem from differences in national tax rates. 
Thus, the national capital-labour ratio, $k_{i}$, is a function of the own national tax rate $\tau_{i}$ and the tax rates in neighbouring countries $\tau_{-i}$. Hence,

$$
k_{i}=k\left(\tau_{i}, \tau_{-i}\right) \quad \forall i
$$

If the government in country $i$ increases the domestic tax rate, the cost of capital in $i$ rises, leading to an outflow of capital. That is, from the point-of-view of country $i$, a reduction in the domestic capital tax rate leads to an increase in the capital-labour ratio whereas a reduction in a neighbouring country's tax rate leads to a lower domestic capital-labour ratio.

Asymmetric country size Bucovetsky (1991) and Wilson (1991) have relaxed the symmetry assumption by considering two countries $a$ and $b$ that are identical in every respect except for the population size, i.e. $s_{a} \neq s_{b}$. The arbitrage condition (1) then reads

$$
f^{\prime}\left(k_{a}\right)-\tau_{a}=f^{\prime}\left(k_{b}\right)-\tau_{b}=\rho
$$

Using the fact that capital market clearing requires $k_{j}=\left(k^{*}-s_{i} k_{i}\right) / s_{j}$, implicit differentiation of (3) yields

$$
\begin{aligned}
& \frac{\partial k_{i}}{\partial \tau_{i}}=\frac{1}{f^{\prime \prime}\left(k_{i}\right)+\frac{s_{i}}{s_{j}} f^{\prime \prime}\left(k_{j}\right)}<0 \quad \forall \quad i, \quad i \neq j \\
& \frac{\partial k_{i}}{\partial \tau_{j}}=\frac{1}{-\left[f^{\prime \prime}\left(k_{i}\right)+\frac{s_{i}}{s_{j}} f^{\prime \prime}\left(k_{j}\right)\right]}>0 \quad \forall \quad i, \quad i \neq j
\end{aligned}
$$

For simplicity assume that country $a$ is larger than country $b .{ }^{11}$ It is easily shown that the small country's per capita capital stock is more responsive with respect to a change in the own tax rate compared to the large country, that is, $\frac{\partial k_{b}}{\partial \tau_{b}}<\frac{\partial k_{a}}{\partial \tau_{a}} \cdot{ }^{12}$ It suffices to show that the denominator in (4) is larger for the small than for the large country. Accordingly, after rearranging terms, we obtain $f^{\prime \prime}\left(k_{b}\right)\left(1-\frac{s_{a}}{s_{b}}\right)>f^{\prime \prime}\left(k_{a}\right)\left(1-\frac{s_{b}}{s_{a}}\right)$ since $s_{a}>s_{b}$. By the same line of argument it is easily shown that the cross tax elasticity of the small country's capital stock per head is higher than that of the large country, i.e. $\frac{\partial k_{b}}{\partial \tau_{a}}>\frac{\partial k_{a}}{\partial \tau_{b}}$. Intuitively, in a two country world a tax-induced capital outflow from the large country necessarily benefits the small country more than it harms the large country if measured in per capita terms. Bucovetsky (1991) and Wilson (1991) show that the large country has a weaker incentive to attract capital via tax rate reductions because, by doing so, it will contribute to a rise in the interest rate, i.e. it will partially offset the reduction in the cost of capital. Therefore, in equilibrium, the large country sets a higher tax rate than the small country.

\footnotetext{
${ }^{11}$ Note that in a symmetric model, the term $s_{i} / s_{j}$ cancels.

${ }^{12}$ Since the own tax elasticities are negative, the elasticity of small countries is smaller only in relative terms.
} 


\section{The econometric specification}

\subsection{The model}

Econometric studies focusing on capital tax competition between countries typically consider tax reaction functions of the general form $\tau_{i}=\tau\left(\tau_{-i}\right)$ to assess the spatial interdependence in the tax setting behaviour. ${ }^{13}$ By contrast, we follow Brett and Pinkse (2000) and Buettner (2003) and analyse tax competition by estimating a tax base function that builds upon the theoretical literature. Since the most important source of capital tax revenue consists of corporate income, ${ }^{14}$ and for reasons mentioned in the introduction, we focus on the corporate profit tax base rather than the capital stock. In accordance, we specify the tax base as

$$
b_{i t}=\lambda_{0}+\lambda_{1} \tau_{i t-1}+\lambda_{2} \bar{\tau}_{i t-1}+X_{i t}^{\prime} \lambda_{x}+\mu_{i}+\epsilon_{i t}
$$

where

$$
\bar{\tau}_{i t}=\sum_{j} \omega_{i j t} \tau_{j t} \quad \text { and } \quad \omega_{i j t}=0 \quad \forall i=j
$$

and where the subscripts $i$ and $j$ denote the country dimension $i, j=1,2, \ldots 14$ and $t$ denotes the time dimension $t=1,2, \ldots, 23$. The considered specification is a panel time series model with unobserved time-invariant individual effects $\mu_{i}$. The country effects are assumed to be fixed parameters as we are interested in exploiting the correlation between the tax base and the tax rates only within countries and not between them. For the same reason we do not include time dummies as this would allow for cross-sectional correlation. ${ }^{15}$ As investors need time to react to changes in domestic and foreign tax policies, the level of reported taxable profits, $b_{i t}$, is assumed to depend on the tax rates in the previous year. We denote the domestic and the weighted neighbouring tax rates as $\tau_{i t-1}$ and $\bar{\tau}_{i t-1}$, respectively.

If taxable profits are indeed mobile and attracted by lower CIT rates across countries, a fall in a neighbouring country's tax rate would result in a decrease of the own tax base, reflected by a positive cross tax elasticity. By contrast, the effect of the own tax rate, $\tau_{i t-1}$, on the tax base is expected to be negative. Since the number of neighbouring countries' tax rates to be considered in our model is relatively large, we follow Anselin (1988) and posit a structure of spatial dependence between the countries, which enables us to estimate only one parameter, namely, $\lambda_{2}$. This is done by defining several weighting schemes $\omega_{i j t}$ that reflect the geographic or economic proximity between countries, where the details are relegated to section 3.2. $X_{i t}$ includes variables that reflect a country's macro-economic performance and factors that affect its relative attractiveness as a production and investment location. ${ }^{16}$

In specification (6) we assume that the tax base elasticities are equal across

\footnotetext{
${ }^{13}$ See Devereux et al. (2002a), Altshuler and Goodspeed (2002) and Redoano (2007).

${ }^{14}$ See Eurostat (2005).

${ }^{15}$ For econometric details see Verbeek (2004).

${ }^{16}$ The considered control variables are discussed in more detail in section 3.3 and in the appendix A.2.
} 
countries. Following Bucovetsky (1991) and Wilson (1991) we shall relax this assumption and discriminate between large and small countries by allowing for different slope parameters, such that the unrestricted model will be of the form

$$
\begin{aligned}
b_{i t}=\lambda_{0}+\lambda_{1} \tau_{i t-1} & +\lambda_{2} \tau_{i t-1}^{\text {large }} \\
& +\lambda_{3} \bar{\tau}_{i t-1}+\lambda_{4} \bar{\tau}_{i t-1}^{\text {large }}+X_{i t}^{\prime} \lambda_{x}+\mu_{i}+\epsilon_{i t}
\end{aligned}
$$

where $\tau_{i t-1}^{\text {large }}$ and $\bar{\tau}_{i t-1}^{\text {large }}$ are the respective tax rates multiplied by the dummy variable of large countries (cf. section 4 for the categorisation of country size). As already mentioned, according to theoretical predictions the tax base elasticities of large countries are expected to be smaller, i.e. $\lambda_{2}>0$ and $\lambda_{4}<0$.

\subsection{Alternative specifications of spatial interdependence among countries}

Let us now turn to the question of how to best define relative country proximity. Since, due to technical reasons discussed in section 3.1, we need to collect the data of all neighbouring countries' CIT rates in one single variable, and because of relative differences between countries' linkages, it is not a trivial task to construct a meaningful weighted neighbouring CIT rate vector. Ideally, one would have full information about the channels that determine why and how some country $j$ 's CIT policy should exert influence on country $i$ 's CIT base. Under the given circumstances, from the point-of-view of a particular country, it appears to be sensible to attribute a weight to every other individual country's CIT rate on the basis of the extent to which that country is likely to be perceived as a substitute investment location by corporations.

As is standard in the spatial interdependence literature we propose several definitions of proximity. One criterion frequently used is that of geographic proximity between two countries. The motivation for this measure is given by the fact that the costs of transportation between two countries usually increase with the distance between them. On the other hand, the availability of investmentrelevant information on market and country characteristics decreases (or, alternatively, the costs of such information increase) with distance. Therefore, geographic proximity weights may capture the ease with which corporations may circumvent higher CIT rates in a particular country by means of relocating assets to some other country. In order to assign higher values to countries that are relatively close, we define a distance weight, $\omega_{i j}^{\text {dist }}$, between some country $j$ and a country $i$ as the inverse of the relative distance, i.e.,

$$
\omega_{i j}^{d i s t}=\frac{1}{\operatorname{dist}_{i j}} / \frac{1}{\sum_{j} d i s t_{i j}}
$$

Given the large amount of intra-industry trade between the countries in our sample, profit shifting opportunities should be substantial. ${ }^{17}$ To the extent that the

\footnotetext{
${ }^{17}$ This link is discussed in Bartelsman and Beetsma (2003).
} 
share of intra-industry trade between two countries is negatively related to the distance between them (see Venables et al. (2003)), the distance weights might also pick up income shifting activities.

A subset of our sample consists of countries that underwent deep economic transformations over the time period considered. Moreover, there have been three rounds of EU enlargement, namely, the "southern" enlargement in 1986, the "northern" enlargement in 1995, and, finally, the first " eastern" enlargement in 2004. Thus, weighting schemes including relevant time-varying data are likely to better reflect changes in interdependence and lead to more accurate estimation results. Following Case et al. (1992) we alternatively define neighbours as countries exhibiting similar economic characteristics. Specifically, countries with similar economic and social development levels are likely to be conceived by investors as equally attractive locations for horizontal FDI, in which case the difference in per capita GDP between any two countries at a given point in time reflects the degree of interdependence:

$$
\omega_{i j t}^{e c o}=\frac{1}{\left|G D P c a p_{i t}-G D P c a p_{j t}\right|} / \frac{1}{\sum_{j}\left|G D P c a p_{i t}-G D P c a p_{j t}\right|}
$$

where $G D P$ cap $_{i t}=G D P_{i t} /$ population $_{i t}$.

Motivated by Devereux et al. (2004) we also consider uniform weights,

$$
\omega_{i j}^{u n i}=\frac{1}{N-1}
$$

which, by definition, do not contain any assumptions on the spatial connection between countries and therefore serve as a benchmark. In fact, the resulting vector of neighbouring tax rates, $\sum_{j} \omega_{i j}^{u n i} \tau_{j}$, closely resembles the (unweighted) average European tax rate which might be a relevant determinant for investors outside Europe facing the option between investing in Europe and investing elsewhere.

Finally, we propose a composite weight that adds a spatial component to the uniform weights, which we denote as contiguity weight, $\omega_{i j}^{\text {cont }}$, given by

$$
\omega_{i j}^{c o n t}=0.5 \omega_{i j}^{u n i}+0.5 \omega_{i j}^{\text {border }}
$$

where $\omega_{i j}^{\text {border }}$ is a binary weight that takes on the value 1 if $i$ and $j$ have a common border ${ }^{18}$ and $\omega_{i j}^{\text {border }}=0$ otherwise.

In order to facilitate interpretation, all weighting matrices are row standardised.

\subsection{Data}

We estimate our specification using annual data for a panel of 14 European countries $^{19}$ where the period covered is 1982 to 2004 . The data, listed in tables

\footnotetext{
${ }^{18}$ If a country $i$ borders the sea and the nearest coast-to-coast distance between $i$ and another country $j$ is below 140 kilometers we also attach a weight of 1 . This applies to the following country pairs: BE-UK, DE-SE, FR-UK, GR-IT, IE-UK, NL-UK.

${ }^{19}$ Our selection of countries is based upon the availability of effective tax rate data. Accordingly, our sample is composed of AT, BE, CH, DE, ES, FI, FR, GR, IE, IT, NL, NO, SE and
} 
5 and 7 in appendix A.2, constitutes a balanced panel data set comprising a total of 322. The CIT base is the amount of firms' profits subject to the nominal corporate income tax. Following Buettner (2003), we derive the tax base by dividing the tax revenues from corporate profits by the statutory tax rate. We use CIT revenues reported by the OECD Revenue Statistics. Note that this data is partly listed on a cash basis, i.e., tax revenues are recorded at the time at which the tax liability is paid. Since tax liabilities are usually paid with a one-year delay, we specify the tax base as $b_{i t}=$ CITrev $_{i t+1} / \tau_{i t}$. For tax revenues reported on accrual basis, where revenues are recorded when the liability is created, the tax base is defined as $b_{i t}=C I T r e v_{i t} / \tau_{i t}$.

The second crucial variable in our empirical setting is the tax rate on corporate profit. We use two measures of the tax rate. Following Devereux (2007) we employ the EATR to reflect more accurately the tax burden incurred by corporations. As already mentioned, the EATR captures both instruments that governments have at their disposal to determine the CIT system, namely the statutory tax rate and the set of rules that specify the extent of profits subject to taxation. In this regard, Devereux and Griffith (1998) suggest that the EATR is the relevant decision variable not only for domestic corporations' discrete investment choices, but also for the choice of location by transnational firms because it measures the extent to which the pre-tax profit is reduced by taxation. On the other hand, the statutory tax rate may also have its merits in explaining the tax base for at least two reasons. First, and contrary to the EATR, the statutory tax rate is common knowledge and does not require detailed information on specific tax deduction rules. Therefore, it might be the case that corporations use the statutory tax rate rather than the EATR as a reference when making domestic and foreign investment as well as portfolio decisions. Second, to the extent that MNEs are able to exploit all potential deductions and allowances in each of their affiliates, their excess income is taxed at the statutory rate. Thus, profit shifting, which also contributes to changes in the tax base is likely to be determined by the statutory tax rate. For these reasons we report results for both tax rate measures. The three fiscal variables, $\tau_{i t}, \bar{\tau}_{i t}$ and $b_{i t}$ are expressed in logarithmic form so that the estimated coefficients can be interpreted as elasticities.

Additionally to the tax rate, several control variables which are likely to affect the tax base are considered. They comprise factors that reflect a country's macro-economic performance and factors that influence its relative attractiveness as an investment location. Accordingly, high labour costs are expected to deter real investment whereas large economies, measured by GDP, are likely to attract foreign direct and portfolio investment. ${ }^{20}$ These variables are assumed to impact on the tax base with a one-period lag, as companies need time to adjust to new economic conditions and because they typically base their investment decisions on turnovers achieved in the previous period. Moreover, we assume that firms base their investment plans on available growth data. Note

UK. Due to missing CIT base data we have to omit PT. However, we do include Portuguese tax rate data in the construction of weighted neighbouring CIT rates.

${ }^{20}$ See Desai and Dharmapala (2007). 
that growth and GDP are not only relevant for cross-border location decisions but they also directly affect the profits of domestically located corporations. Moreover, the availability of national energy sources is assumed to impact positively on the tax base. ${ }^{21}$ In particular, it is likely that the discovery of new oil sources in various countries gave substantial rise to reported profits. Finally, as the tax base is measured in nominal terms inflation is included as a regressor.

\section{Estimation}

Two special econometric issues arise when estimating the model outlined in section 3.1. First, the tax rate $\tau_{i t-1}$ is potentially endogenous in equation (6) since the tax base is partly generated by dividing tax revenues by the lagged statutory tax rates. Moreover, since by reference to the theoretical and empirical literature countries' tax rates are jointly determined, $\bar{\tau}_{i t-1}$ is also potentially correlated with the error term. Thus, the fiscal variables may not be estimated consistently by OLS, requiring instrumental variables (IV) techniques. Second, although we control for spatial interdependence resulting from strategic tax setting behaviour, contemporaneously correlated errors may arise simply due to similar geographical conditions in adjacent countries. Although the presence of spatial heteroskedasticity does not result in biased estimates it can overstate the effect of neighbouring countries' tax rates on the own tax base (Brueckner (2003)). In order to improve efficiency and avoid biased standard errors we control for spatial error dependence. We will consider these issues in turn.

\subsection{Instrumental variables}

Estimates obtained under IV techniques are sensitive to the choice of instruments in that their consistency crucially depends on the degree of instrument relevance, i.e. the correlation between instruments and explanatory variables. A commonly used instrument potentially explaining a large part of the variation is the lag of the endogenous variable. Thus we include one-year lags of the domestic and neighbouring tax rates. Additionally, based upon the theory of asymmetric tax competition and suggested by our data, we can also exploit the notion that larger countries generally set higher tax rates. Therefore, a country's national tax rate is expected to be positively related to its population. The unemployment rate is also a potential instrument for the tax rates since policymakers mainly aim at attracting physical capital in order to fight unemployment. Accordingly, a rise in the fraction of jobless residents may strengthen a government's motivation to lower the corporate tax rate so as to stimulate

\footnotetext{
${ }^{21}$ The countries considered in our sample are very heterogeneous concerning their access to natural sources of energy. Norway, in particular, greatly benefited from the discovery and exploration of rich subsea oil and gas deposits from the 1970s onwards. Between 1982 and 2004 Norway exported on average nearly five times as much fuel as the second largest exporter in our sample, The Netherlands.
} 
investment and to avoid that firms relocate production abroad. ${ }^{22}$ Applying the first differences of population and unemployment, as well as the lagged tax rates, the Hansen J-statistic of overidentifying restrictions confirms the validity of our instruments, i.e. the instruments are uncorrelated with the errors. This applies to all weighting schemes outlined in section 3.2 regardless of whether the statutory or the effective tax rate is used. The Hausman test for endogeneity indicates that the domestic tax rate is endogenous under every weighting specification while the neighbouring tax rate variable is only endogenous if uniform weights are applied. ${ }^{23}$ Recently, advances have been made regarding the strength of instruments. When only one tax rate variable is endogenous, we can test for weak identification in the presence of heteroscedasticity and autocorrelation. Thus, with the exception of uniformly weighted tax rates, we calculate the first-stage F-statistic. Considering the critical values of Stock and Yogo (2002), we conclude that our set of instruments is strong in the sense that the two-stage least squares' relative bias is at most $5 \% .{ }^{24}$ In order to exogenize the tax rates we regress them on all exogenous variables including the above discussed instruments via OLS. ${ }^{25}$ For details on the measurement and the sources of the considered variables see the appendix A.2.

\subsection{Spatial error dependence}

In a cross section (panel) world, the conventional method of accounting for interdependence in the errors across individuals consists of imposing a spatial covariance structure of the form $e_{i}=\rho \sum_{j} w_{i j} e_{j}+u_{i}$, where $u_{i}$ is assumed to be

\footnotetext{
${ }^{22}$ On the other hand, a rise in the unemployment rate is typically associated with higher social transfers which are to a great extent financed by taxes levied on labour and social security contributions which are partly paid by employers. Yet, since the collection of corporate revenue is likely to be unrelated to a country's welfare expenditures (see Clausing (2007)) we do not expect unemployment to have a positive impact on the rate at which profits are taxed. Actually, in view of the fact that firm mobility and firm profitability are strongly correlated (Devereux et al. (2002b)), governments might be inclined to compensate employers for the rise in social contributions by reducing the rate at which profits are taxed in order to avoid relocation.

${ }^{23}$ Accordingly, the uniform weighting scheme requires the instrumentation of both domestic and foreign tax rates, whereas in the remaining weighting specifications the neighbouring tax rate appears as an exogenous regressor and thus its lagged value does not enter the list of instruments.

${ }^{24}$ Expressing unemployment and population in first differences rather than in levels greatly improved the p-value of the Hansen J-statistic indicating that lagged variables perform worse as instruments. It is noteworthy that without the inclusion of the lagged tax rate the reported first stage F-statistic is far below the critical value required for a less than $30 \%$ bias. Instrumentation without the lagged tax rate results in a severe overestimation of the tax elasticities. Note that the inclusion of additional instruments typically considered in the tax competition literature, such as the proportion of young and old residents, as well as an election year dummy and left and right wing government dummies, does neither alter the respective test statistics nor the estimates. The same holds if we also include a subset of variables weighted by the respective proximity concepts.

${ }^{25}$ Note that we are performing 2 SLS manually, where we use the predicted variables as regressors in the second estimation stage. However, we do not have to adjust the standard errors of the second stage regression since we observe very high $R^{2}$ in the first stage equation (Gujarati (2003, p. 791)).
} 
iid with mean zero and covariance matrix $\sigma_{u}^{2} I_{n}$. Since the spatial lag, $\sum_{j} w_{i j} e_{j}$, is correlated with the error term $u_{i}$, the OLS estimator of $\rho$ yields biased results (Anselin (1988)). This problem is typically addressed by maximum likelihood estimation techniques or, more recently, by GMM methods as proposed in Kelejian and Prucha $(1998,1999,2006)$ and Kelejian et al. (2007).

Since we have a time-series panel model we apply an approach first proposed in Parks (1967) and discussed in Kmenta (2003) which has the advantage of controling for the error dependence across countries without having to impose an a priori specified spatial covariance structure. This is of particular importance as we have no information on the nature of interaction over space within the errors. Specifically, since our time dimension fairly exceeds the number of countries, we can extract the spatial relation directly from the data by applying OLS on the fitted residuals obtained from the consistent first step estimation. This results in $(N-1) N / 2$ covariance pairs reflecting the time-invariant spatial correlation across countries, i.e., $E\left(\epsilon_{i t} \epsilon_{j t}\right)=\sigma_{i j}^{2}$. Indeed, a Breusch-Pagan LM test for independence of errors across countries confirms the assumption of contemporaneous correlation. The estimated error structure will be considered by applying a feasible GLS estimator to obtain efficient results.

This estimator is implemented by using the xtgls command of the Stata software where the contemporaneous error structure can be accounted for via the option panels(correlated). Moreover, in order to account for panel-specific serial correlation in the errors, we consider the respective coefficients to transform the observations by employing the option corr(psar1). The advantages of the Parks-Kmenta estimator come with the drawback that the number of time periods has to be large enough compared to $\mathrm{N}$ so as to estimate the required parameters accurately. As Beck and Katz (1995) point out, standard errors can be underestimated if $\mathrm{T}$ is not sufficiently large. In a Monte Carlo analysis they show that the underestimation occurs more frequently when $\mathrm{T}$ is less than three times N, which applies to our panel structure. They propose estimating the coefficients via OLS and correcting the variability of the coefficient estimates by considering the contemporaneous correlation of the errors. To assure that our coefficients of interest are not erroneously reported as being significant, we reestimate equation (6) applying their proposed procedure which we report in addition to the Parks-Kmenta estimates. ${ }^{26}$

For estimating the restricted model we apply a general to specific strategy. ${ }^{27}$ That is, the complete specification is estimated and the variable with the highest p-value is dropped from the model one at a time. The final version includes only variables that are significant at least at the $10 \%$ level, where the joint significance of the country dummies is tested within each step.

\footnotetext{
${ }^{26}$ This is done by using the $x t p c s e$ command of the Stata Software where groupwise serial correlation is considered via the option $\operatorname{corr}$ (psar1).

${ }^{27}$ Prior to estimation we perform several robustness checks including an outlier inspection and a multicollinearity (MC) analysis indicating that no severe outliers and MC effects are present. We report pairwise correlation coefficients of the regressors in table 6 in appendix A.2.
} 


\subsection{Asymmetric country size}

The final specification is re-estimated by allowing for different tax base elasticities within large and small countries. This is done by additionally adding a domestic and foreign tax rate variable that are multiplied with the dummy for large countries so that significant coefficients on the interacted variables indicate that the tax base elasticities are different. We find that several macroeconomic variables, namely, total GDP, the net capital stock and the gross fixed capital formation result in a similar country ranking by size. We define countries lying above the respective average value of any of these variables as large and vice versa. This approach specifies DE, FR, UK, IT and ES as large countries, and NL, CH, SE, BE, AT, NO, FI, IE and GR as small countries.

\section{$5 \quad$ Results}

The estimation results for the general model, where tax policies are constrained to have the same effect in all countries (see equation (6)), are reported in table 1 for statutory tax rates and in table 2 for EATR. Due to space limitations we only report a representative subset of the overall results. ${ }^{28}$ Accordingly, the first two columns contain the estimations based on uniform weights, while the remaining two columns show the results based on distance weights. We confront our proposed Parks-Kmenta estimator in columns (1) with the results obtained from an alternative estimator in columns (2), that delivers panel corrected standard errors (Beck and Katz (1995)).

As predicted by the standard tax competition theory, the CIT base is negatively affected by the own tax rate whereas the coefficient on the weighted neighbouring tax rates is positive. The estimated elasticities are significant and consistent not only throughout all applied weighting schemes but also regarding both measures of the tax rate, i.e. statutory and effective average CIT rates. The estimation results confirm that corporations clearly undertake efforts in comparing national tax policies and that they react to international tax differentials.

Regarding the effect of the control variables on the tax base, a clear picture arises. As expected, GDP, growth, inflation, and national sources of energy impact positively whereas labour costs impact negatively on the national tax base. It is noteworthy that the results remain remarkably similar in sign and magnitude throughout all specifications. Country dummies are jointly significant in all specifications. ${ }^{29}$ The first-stage robust F-statistics for the distance weights specifications are clearly well above the critical value, indicating that our regression does not suffer from a weak instrument problem.

A comparison reveals that the more efficient Parks-Kmenta estimator does not lead to an overconfidence of the fiscal coefficients. Moreover, as mentioned

\footnotetext{
${ }^{28}$ The results for the remaining specifications are available on request

${ }^{29}$ Inclusion of a time trend to account for the sustained rise in the tax base proved to be insignificant and highly correlated with neighbouring tax rates.
} 
Table 1: Symmetric country size. Statutory tax rate specification.

\begin{tabular}{|c|c|c|c|c|}
\hline \multirow{2}{*}{$\begin{array}{l}\text { Dep. variable: } \ln \text { tax } \text { base }_{i t} \\
\text { Variable }\end{array}$} & \multicolumn{2}{|c|}{$\omega_{i j}^{u n i}$} & \multicolumn{2}{|c|}{$\omega_{i j}^{d i s t}$} \\
\hline & (1) & $(2)$ & (1) & $(2)$ \\
\hline \multirow[t]{2}{*}{$\ln \tau_{i t-1}$} & $-0.330^{* * *}$ & $-0.409^{* * *}$ & $-0.403^{* * *}$ & $-0.464^{* * *}$ \\
\hline & $(0.032)$ & $(0.079)$ & $(0.031)$ & $(0.094)$ \\
\hline \multirow[t]{2}{*}{$\ln \bar{\tau}_{i t-1}$} & $0.806^{* * *}$ & $1.156^{* * *}$ & $0.582^{* * *}$ & $0.683^{* *}$ \\
\hline & $(0.144)$ & $(0.349)$ & $(0.088)$ & $(0.276)$ \\
\hline \multirow[t]{2}{*}{ Growth $_{i t}$} & $0.011^{* * *}$ & $0.009^{* *}$ & $0.011^{* * *}$ & $0.011^{* *}$ \\
\hline & $(0.001)$ & $(0.005)$ & $(0.001)$ & $(0.005)$ \\
\hline \multirow[t]{2}{*}{$\ln \mathrm{GDP}_{i t-1}$} & $1.722^{* * *}$ & $1.818^{* * *}$ & $1.553^{* * *}$ & $1.550^{* * *}$ \\
\hline & $(0.070)$ & $(0.259)$ & $(0.052)$ & $(0.204)$ \\
\hline \multirow[t]{2}{*}{$\mathrm{ULC}_{i t-1}$} & $-0.995^{* * *}$ & $-1.025^{* * *}$ & $-0.900^{* * *}$ & $-0.928^{* * *}$ \\
\hline & $(0.056)$ & $(0.176)$ & $(0.040)$ & $(0.166)$ \\
\hline \multirow[t]{2}{*}{ Energy $_{i t}$} & $0.011^{* * *}$ & $0.008^{* * *}$ & $0.011^{* * *}$ & $0.009^{* * *}$ \\
\hline & $(0.002)$ & $(0.002)$ & $(0.001)$ & $(0.003)$ \\
\hline \multirow[t]{2}{*}{ Inflation $_{i t}$} & $0.005^{* * *}$ & $0.006^{* * *}$ & $0.005^{* * *}$ & $0.005^{* * *}$ \\
\hline & $(0.001)$ & $(0.001)$ & $(0.001)$ & $(0.001)$ \\
\hline \multirow[t]{2}{*}{ Constant } & $-2.080^{* * *}$ & $-2.080^{* * *}$ & $-2.026^{* * *}$ & $-1.986^{* * *}$ \\
\hline & $(0.091)$ & $(0.254)$ & $(0.085)$ & $(0.242)$ \\
\hline $\mathrm{N}$ & 294 & 294 & 294 & 294 \\
\hline Country dum. $\chi_{(13)}^{2}$ & $379.34^{* * *}$ & $211.53^{* * *}$ & $801.90^{* * *}$ & $474.68^{* * *}$ \\
\hline R-squared & & 0.91 & & 0.88 \\
\hline First-stage robust F-test & & & 70.27 & 70.27 \\
\hline (Stock-Yogo critical value & & & & \\
\hline for $5 \%$ max. IV rel. bias) & & & $(13.91)$ & $(13.91)$ \\
\hline
\end{tabular}

Significance levels : $\quad *: 10 \% \quad * *: 5 \% \quad * * *: 1 \%$

Notes: Columns (1) contain estimation results obtained ¿from a two-stage feasible GLS procedure which corrects for the contemporaneous error structure (Parks-Kmenta estimator). Columns (2) are the result of 2SLS with spatial-robust errors (Beck and Katz (1995))

by Brueckner (2003), we observe that the size of the coefficients is magnified if spatial correlation is not accounted for.

Interestingly, the tax base is more sensitive to changes in the statutory tax rate than it is to changes in the EATR. The results point to the preeminence of the statutory tax rate over the EATR as a determinant for taxable corporate profits. This could have several explanations. First, the tax base variability may to a large extent be explained by the shifting of pure accounting income within units of MNEs which are taxed at the national statutory rate. A number of recent empirical contributions based on firm-level data confirm the importance of profit shifting. ${ }^{30}$ Second, it is plausible that corporations on average

\footnotetext{
${ }^{30}$ See Bartelsman and Beetsma (2003) for a recent empirical analysis of the importance of profit shifting activities among OECD countries. Huizinga and Laeven (2007) examine the extent of intra-European profit shifting by European multinationals. Weichenrieder (2007)
} 
Table 2: Symmetric country size. EATR specification.

\begin{tabular}{|c|c|c|c|c|}
\hline \multirow{2}{*}{$\begin{array}{l}\text { Dep. variable: } \ln \text { tax } \text { base }_{i t} \\
\text { Variable }\end{array}$} & \multicolumn{2}{|c|}{$\omega_{i j}^{u n i}$} & \multicolumn{2}{|c|}{$\omega_{i j}^{d i s t}$} \\
\hline & (1) & $(2)$ & (1) & $(2)$ \\
\hline \multirow[t]{2}{*}{$\ln \tau_{i t-1}$} & $-0.261^{* * *}$ & $-0.300^{* * *}$ & $-0.293^{* * *}$ & $-0.330^{* * *}$ \\
\hline & $(0.027)$ & $(0.083)$ & $(0.027)$ & $(0.089)$ \\
\hline \multirow[t]{2}{*}{$\ln \bar{\tau}_{i t-1}$} & $0.623^{* * *}$ & $0.836^{* * *}$ & $0.425^{* * *}$ & $0.522^{* *}$ \\
\hline & $(0.141)$ & $(0.326)$ & $(0.090)$ & $(0.263)$ \\
\hline \multirow[t]{2}{*}{ Growth $_{i t}$} & $0.010^{* * *}$ & $0.009^{*}$ & $0.010^{* * *}$ & $0.010^{* *}$ \\
\hline & $(0.001)$ & $(0.005)$ & $(0.001)$ & $(0.005)$ \\
\hline \multirow[t]{2}{*}{$\ln \mathrm{GDP}_{i t-1}$} & $1.866^{* * *}$ & $1.943^{* * *}$ & $1.709^{* * *}$ & $1.747^{* * *}$ \\
\hline & $(0.088)$ & $(0.267)$ & $(0.065)$ & $(0.212)$ \\
\hline \multirow[t]{2}{*}{$\mathrm{ULC}_{i t-1}$} & $-1.101^{* * *}$ & $-1.216^{* * *}$ & $-1.016^{* * *}$ & $-1.111^{* * *}$ \\
\hline & $(0.071)$ & $(0.191)$ & $(0.058)$ & $(0.170)$ \\
\hline \multirow[t]{2}{*}{ Energy $_{i t}$} & $0.012^{* * *}$ & $0.010^{* * *}$ & $0.012^{* * *}$ & $0.010^{* * *}$ \\
\hline & $(0.001)$ & $(0.003)$ & $(0.001)$ & $(0.003)$ \\
\hline \multirow[t]{2}{*}{ Inflation $_{i t}$} & $0.003^{* * *}$ & $0.003^{* * *}$ & $0.003^{* * *}$ & $0.003^{* *}$ \\
\hline & $(0.0005)$ & $(0.001)$ & $(0.001)$ & $(0.001)$ \\
\hline \multirow[t]{2}{*}{ Constant } & $-2.183^{* * *}$ & $-2.082^{* * *}$ & $-2.198^{* * *}$ & $-2.131^{* * *}$ \\
\hline & $(0.111)$ & $(0.217)$ & $(0.100)$ & $(0.214)$ \\
\hline $\mathrm{N}$ & 294 & 294 & 294 & 294 \\
\hline Country dum. $\chi_{(13)}^{2}$ & $654.48^{* * *}$ & $355.92^{* * *}$ & $1446.88^{* * *}$ & $736.82^{* * *}$ \\
\hline R-squared & & 0.90 & & 0.87 \\
\hline $\begin{array}{l}\text { First-stage robust F-test } \\
\text { (Stock-Yogo critical value }\end{array}$ & & & 118.92 & 118.92 \\
\hline for $5 \%$ max. IV rel. bias) & & & $(13.91)$ & $(13.91)$ \\
\hline
\end{tabular}

Significance levels : $\quad *: 10 \% \quad * *: 5 \% \quad * * *: 1 \%$

Notes: Columns (1) contain estimation results obtained ¿from a two-stage feasible GLS procedure which corrects for the contemporaneous error structure (Parks-Kmenta estimator). Columns (2) are the result of 2SLS with spatial-robust errors (Beck and Katz (1995))

are poorly informed about the effective tax burden and therefore largely rely on differences in statutory tax rates in their investment and location decisions. Third, the results could be attributed to the enhanced role of MNEs' access to global diversification opportunities, in particular, to the role of foreign portfolio investment as a diversification vehicle. In a recent paper Desai and Dharmapala (2007) find that the statutory corporate tax rate is a significant determinant for the ratio of US foreign portfolio investment to foreign direct investment. Depending on the spatial weighting scheme, the tax base elasticity with respect to the own statutory tax rate lies between -0.33 and -0.40 . Transforming the coefficient estimate for the specification where spatial interdependence between

analyses profit shifting behaviour within MNEs using data on German inbound and outbound FDI. 
countries is reflected by geographic proximity, into a semi-elasticity, our results suggest that a 1 percentage point increase in a country's statutory tax rate leads to a $0.84 \%$ decline in reported domestic before-tax income.

The coefficient on the weighted neighbouring countries' statutory tax rates ranges between 0.58 and 0.81 . Taken literally, these values reflect the average percentage response of a country's tax base if all 13 neighbours simultaneously raise their tax rates by $1 \%{ }^{31}$ In order to obtain an estimate for the effect of an individual neighbouring country $j$ 's tax rate on the tax base of country $i$, the estimated parameter $\lambda_{2}$ must be multiplied with the respective weight, i.e. $\partial b_{i t} / \partial \tau_{j t-1}=\lambda_{2} \omega_{i j}$. For the purpose of illustration, take the case of uniform weights. From the point-of-view of a country $i$, a unilateral reduction in any one neighbouring country's statutory tax rate by $1 \%$ leads to a $0.062 \%$ reduction in country $i$ 's tax base. ${ }^{32}$

Likewise, taking into account distance weighted tax rates we can explicitly extract how each country's tax rate affects another country's tax base. That is, we obtain a matrix of cross-country base elasticities as shown in appendix A.1. For instance, Belgium's tax base is shown to fall by $0.02 \%(0.04 \%)$ if Finland unilaterally decreases its statutory tax rate by $1 \%$ (1\% point) whereas it falls by $0.12 \%(0.21 \%)$ if The Netherlands decrease their tax rate by $1 \%$ ( $1 \%$ point). In view of the estimated elasticities we can conclude that the lowering of the CIT rates between 1982 and 2004 in Western Europe has only mildly contributed to the observed rise in CIT bases as shown in figure 1. In view of these elasticities, the evolution of CIT rates throughout the observed time period cannot explain the rise in CIT revenues.

Asymmetric country size The results of the unrestricted model are reported in tables 3 and 4 for statutory and effective tax rates, respectively. We find that the estimated coefficients on the own countries' tax rates in large countries are only significantly different from those in small countries if we consider EATR. Thus we can partly confirm the result obtained by Bucovetsky (1991) and Wilson (1991) regarding the weaker tax base responsiveness to the own tax rate in large countries. Interestingly, we find a reversed picture concerning the tax base elasticity with respect to neighbouring countries' tax rates. Specifically, the cross tax elasticity is significantly higher in large countries, regardless of which tax rate measure is applied.

Even though small countries exhibit higher own tax elasticities in the EATR specification, the tax base is nevertheless shown to be inelastic. Faced with a global tax reduction trend, large countries are in a disadvantageous position for two reasons. On the one hand, own tax reductions prove to be a much less powerful instrument to enhance domestic profits. On the other hand, large countries' tax bases are shown to be more sensitive to neighbouring countries'

\footnotetext{
${ }^{31}$ By contrast, if country proximity is defined by similar levels of per capita GDP, i.e. $\omega_{i j}^{e c o}$, the elasticity drops to 0.03 indicating that firms do not perceive countries in the sample with a similar development level barely as much as close substitutes for the location of capital as countries that are geographically close.

${ }^{32} 0.806 \% / 13=0.062 \%$
} 
Table 3: Asymmetric country size. Statutory tax rate specification.

\begin{tabular}{|c|c|c|c|c|}
\hline \multirow{2}{*}{$\begin{array}{l}\text { Dep. variable: } \ln \text { tax } \text { base }_{i t} \\
\text { Variable }\end{array}$} & \multicolumn{2}{|c|}{$\omega_{i j}^{u n i}$} & \multicolumn{2}{|c|}{$\omega_{i j}^{\text {dist }}$} \\
\hline & (1) & $(2)$ & $(1)$ & $(2)$ \\
\hline \multirow[t]{2}{*}{$\ln \tau_{i t-1}$} & $-0.304^{* * *}$ & $-0.325^{* * *}$ & $-0.403^{* * *}$ & $-0.417^{* * *}$ \\
\hline & $(0.037)$ & $(0.099)$ & $(0.035)$ & $(0.113)$ \\
\hline \multirow{2}{*}{$\ln \tau_{i t-1}^{\text {large }}$} & 0.104 & 0.132 & $0.128^{*}$ & 0.204 \\
\hline & $(0.069)$ & $(0.177)$ & $(0.073)$ & $(0.193)$ \\
\hline \multirow[t]{2}{*}{$\ln \bar{\tau}_{i t-1}$} & $0.524^{* * *}$ & $0.574^{*}$ & $0.500^{* * *}$ & $0.519^{*}$ \\
\hline & $(0.086)$ & $(0.300)$ & $(0.081)$ & $(0.277)$ \\
\hline \multirow{2}{*}{$\ln \bar{\tau}_{i t-1}^{\text {large }}$} & $0.793^{* * *}$ & $0.758^{* * *}$ & $0.786^{* * *}$ & $0.768^{* * *}$ \\
\hline & $(0.075)$ & $(0.130)$ & $(0.081)$ & $(0.162)$ \\
\hline \multirow[t]{2}{*}{ Growth $_{i t}$} & $0.008^{* * *}$ & $0.010^{* *}$ & $0.009^{* * *}$ & $0.010^{* *}$ \\
\hline & $(0.001)$ & $(0.005)$ & $(0.001)$ & $(0.005)$ \\
\hline \multirow[t]{2}{*}{$\ln \mathrm{GDP}_{i t-1}$} & $1.845^{* * *}$ & $1.835^{* * *}$ & $1.800^{* * *}$ & $1.785^{* * *}$ \\
\hline & $(0.063)$ & $(0.250)$ & $(0.051)$ & $(0.222)$ \\
\hline \multirow[t]{2}{*}{$\mathrm{ULC}_{i t-1}$} & $1.049^{* * *}$ & $-1.057^{* * *}$ & $-1.034^{* * *}$ & $-1.056^{* * *}$ \\
\hline & $(0.043)$ & $(0.170)$ & $(0.045)$ & $(0.170)$ \\
\hline \multirow[t]{2}{*}{ Energy $_{i t}$} & $0.005^{* * *}$ & 0.004 & $0.006^{* * *}$ & 0.004 \\
\hline & $(0.002)$ & $(0.003)$ & $(0.002)$ & $(0.003)$ \\
\hline \multirow[t]{2}{*}{ Inflation $_{i t}$} & $0.003^{* * *}$ & $0.004^{* * *}$ & $0.003^{* * *}$ & $0.004^{* * *}$ \\
\hline & $(0.001)$ & $(0.001)$ & $(0.001)$ & $(0.001)$ \\
\hline \multirow[t]{2}{*}{ Constant } & $-2.376^{* * *}$ & $-2.419^{* * *}$ & $-2.408^{* * *}$ & $-2.431^{* * *}$ \\
\hline & $(0.101)$ & $(0.250)$ & $(0.092)$ & $(0.255)$ \\
\hline $\mathrm{N}$ & 294 & 294 & 294 & 294 \\
\hline Country dum. $\chi_{(13)}^{2}$ & $1437.98^{* * *}$ & $645.05^{* * *}$ & $1594.89^{* * *}$ & $713.22^{\text {*** }}$ \\
\hline R-squared & & 0.92 & & 0.92 \\
\hline
\end{tabular}

Significance levels : $\quad *: 10 \% \quad * *: 5 \% \quad * * *: 1 \%$

Notes: Columns (1) contain estimation results obtained from a two-stage feasible GLS procedure which corrects for the contemporaneous error structure (Parks-Kmenta estimator). Columns (2) are the result of 2SLS with spatial-robust errors (Beck and Katz (1995)).

tax rates. Obviously, firms in larger countries have more opportunities to take advantage of international tax differentials. In a recent contribution, Desai et al. (2006) show that larger, more international US firms are the most likely to use tax havens. To the extent that firms in more populated countries are more likely to reach the minimum efficient scale necessary to engage in foreign activities, it is conceivable that profit shifting is more substantial in larger countries. 
Table 4: Asymmetric country size. EATR specification.

\begin{tabular}{lcc|cc}
\hline \hline Dep. variable: ln tax base $i t$ & \multicolumn{2}{c}{$\omega_{i j}^{\text {uni }}$} & \multicolumn{2}{c}{$\omega_{i j}^{\text {dist }}$} \\
Variable & $(1)$ & $(2)$ & $(1)$ & $(2)$ \\
\hline $\ln \tau_{i t-1}$ & $-0.300^{* * *}$ & $-0.291^{* * *}$ & $-0.356^{* * *}$ & $-0.352^{* * *}$ \\
& $(0.035)$ & $(0.100)$ & $(0.033)$ & $(0.106)$ \\
$\ln \tau_{\text {it-1 }}^{\text {large }}$ & $0.296^{* * *}$ & $0.281^{*}$ & $0.322^{* * *}$ & $0.334^{* *}$ \\
& $(0.056)$ & $(0.159)$ & $(0.062)$ & $(0.163)$ \\
$\ln \bar{\tau}_{i t-1}$ & $0.386^{* * *}$ & 0.494 & $0.376^{* * *}$ & 0.423 \\
& $(0.091)$ & $(0.282)$ & $(0.083)$ & $(0.263)$ \\
$\ln \bar{\tau}_{i t-1}^{\text {large }}$ & $0.767^{* * *}$ & $0.752^{* * *}$ & $0.750^{* * *}$ & $0.777^{* * *}$ \\
& $(0.076)$ & $(0.144)$ & $(0.083)$ & $(0.166)$ \\
Growth $_{i t}$ & $0.008^{* * *}$ & $0.010^{* *}$ & $0.008^{* * *}$ & $0.010^{* *}$ \\
& $(0.001)$ & $(0.005)$ & $(0.001)$ & $(0.005)$ \\
$\ln$ GDP $_{i t-1}$ & $1.997^{* * *}$ & $1.963^{* * *}$ & $1.971^{* * *}$ & $1.948^{* * *}$ \\
& $(0.077)$ & $(0.252)$ & $(0.070)$ & $(0.219)$ \\
ULC $_{i t-1}$ & $-1.204^{* * *}$ & $-1.215^{* * *}$ & $-1.218^{* * *}$ & $-1.223^{* * *}$ \\
& $(0.049)$ & $(0.178)$ & $(0.057)$ & $(0.176)$ \\
Energy $_{i t}$ & $0.006^{* * *}$ & $0.005^{*}$ & $0.007^{* * *}$ & $0.005^{*}$ \\
& $(0.002)$ & $(0.003)$ & $(0.002)$ & $(0.003)$ \\
Inflation $_{i t}$ & 0.001 & $0.002^{*}$ & 0.001 & $0.002^{*}$ \\
Constant $_{\text {R-squared }}$ & $(0.001)$ & $(0.001)$ & $(0.001)$ & $(0.001)$ \\
& $-2.561^{* * *}$ & $-2.525^{* * *}$ & $-2.599^{* * *}$ & $-2.559^{* * *}$ \\
Nountry dum. $_{(13)}$ & $(0.112)$ & $(0.216)$ & $(0.106)$ & $(0.224)$ \\
\hline \hline
\end{tabular}

Significance levels : $\quad *: 10 \% \quad * *: 5 \% \quad * * *: 1 \%$

Notes: Columns (1) contain estimation results obtained from a two-stage feasible GLS procedure which corrects for the contemporaneous error structure (Parks-Kmenta estimator). Columns (2) are the result of 2SLS with spatial-robust errors (Beck and Katz (1995))

\section{Conclusion}

In the past two decades, an impressive amount of theoretical literature on tax competition has emerged. Recent empirical research associated with this topic has mainly focused on measuring strategic interactions among governments by means of tax reaction functions. In this paper we follow a different approach. In order to identify the underlying mechanism in tax competition models whereby governments strategically undercut each others' tax rates to avoid an outflow of capital, we directly estimate the elasticity of a country's tax base with respect to its own as well as to neighbouring country's tax rates. We tackle this issue by estimating a structural model in the vein of Brett and Pinkse (2000).

We find that corporate income tax bases in Western Europe respond to inter- 
national corporate income tax rate differentials. Thus, we confirm that the results found in the recent tax reaction literature are, at least partly, driven by resource flows. However, compared to the impact of the own tax rate, the tax base elasticity with respect to neighbouring countries' tax policies is only modest. This suggests that a substantial part of domestic business is internationally immobile. Moreover, our results partly support the theoretical prediction in the classic asymmetric tax competition literature which posits that the capital stock of small countries is more responsive to domestic and foreign tax policies (Bucovetsky (1991) and Wilson (1991)). While we find evidence of a higher responsiveness of the tax base to domestic tax rates in small countries we cannot confirm that small countries' tax bases are more sensitive to neighbouring countries' tax rates. On the contrary, larger countries are found to be significantly more affected by foreign countries' tax policies than small countries. This raises the question of the potentially different attitude between small and large countries towards European tax coordination arrangements. If decisions were solely based upon maximising the revenues from corporate taxation, a simultaneous increase in tax rates would generally yield higher tax receipts due to the low base elasticity. Yet, the finding that large countries' taxable income is less elastic with respect to the domestic tax and more elastic concerning neighbouring countries' tax rates suggests that they would be the main beneficiaries of such agreements. This explains why typically the governments of large countries are the most fierce opponents of tax competition whereas small countries generally engage in undercutting each others' tax rates.

It remains to be explained why tax rates in Europe exhibit such a high interdependence. It could be that policymakers overestimate the extent of tax base mobility stimulating them to engage in undercutting each other's tax rates. Alternatively, governments might mimic each other due to rent-seeking behaviour, not least because voters might perceive that low capital taxes are a means of mitigating capital outflows and job relocation. Yet another explanation that could reconcile the apparently disparate results of a high tax rate interdependence and a low tax base mobility could be that a considerable amount of firms is internationally immobile. Governments might direct their tax policy largely towards mobile firms which are generally larger and more profitable than immobile firms. In this context it should be mentioned that business lobbying organisations play an important role in advising governments, thereby influencing the legislative and regulatory framework within which they must operate. 


\section{A Appendix}

\section{A.1 Cross-elasticities}

\begin{tabular}{|c|c|c|c|c|c|c|c|c|c|c|c|c|c|c|c|}
\hline \multirow[b]{2}{*}{ 入_2 $=0.582$} & \multicolumn{15}{|c|}{ Cross-country base elasticities wrt statutory tax rates weighted with the relative distances } \\
\hline & AT & $\mathrm{BE}$ & $\mathrm{CH}$ & DE & ES & $\mathrm{FI}$ & FR & GR & IE & IT & NL & NO & PT & SE & UK \\
\hline $\begin{array}{l}\text { AT } \\
\end{array}$ & 0 & 0.036 & 0.052 & 0.071 & 0.031 & 0.042 & 0.034 & 0.056 & 0.028 & 0.062 & 0.036 & 0.036 & 0.03 & 0.041 & 0.03 \\
\hline $\mathrm{BE}$ & 027 & 0 & 044 & 0.035 & 0.026 & 0.022 & 0.081 & 1 & 37 & 0.025 & 0.12 & 027 & 0.024 & 24 & 0.07 \\
\hline $\mathrm{CH}$ & 5 & 0.056 & 0 & 0.041 & 0.041 & 0 & 0.066 & 6 & 32 & 0.058 & 045 & 0.028 & 35 & 27 & 0.041 \\
\hline DE & 69 & 0.04 & 0.041 & 0 & 0.026 & 0 . & 0.035 & 5 & 31 & 0. & 0.051 & 05 & 26 & 55 & 0.035 \\
\hline ES & 28 & 0.031 & 0.038 & 0.024 & 0 & 0.025 & 0.04 & 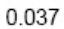 & 9 & 0. & .028 & 25 & 66 & 24 & .035 \\
\hline $\mathrm{FI}$ & 036 & 0.025 & 0.024 & 0.042 & 0.024 & 0 & 0.023 & 37 & 0.029 & 0.027 & 0.028 & 0.078 & 26 & 0.156 & 0.026 \\
\hline FR & 0.028 & 0.09 & 0.058 & 0.03 & 0.038 & 0.023 & 0 & 0.024 & 0.043 & 0.0 & 0.057 & 0. & 34 & 24 & 0.077 \\
\hline GR & 0.06 & 0.03 & 0.04 & 0.038 & 0.044 & 0.046 & 0.031 & 0 & 0.031 & 0.085 & 0.029 & 0. & 0. & 0. & 0.029 \\
\hline IE & 027 & 0.047 & 0.033 & 0.031 & 0.043 & 0.033 & 0.05 & 0.028 & 0 & 0.028 & 0.049 & 0.043 & 0.047 & 0.035 & 0.088 \\
\hline IT & 063 & 0.033 & 0.061 & 0.037 & 0.048 & 0.032 & 0.037 & 0.08 & 0.029 & 0 & 0.031 & 0.028 & 0.0 & 0.03 & 0.03 \\
\hline $\mathrm{NL}$ & 029 & 0.126 & 0.037 & 0.042 & 0.025 & 0.027 & 0.054 & 0.022 & 0.041 & 0.024 & 0 & 0.035 & 0.024 & 0.03 & 0.068 \\
\hline NO & 031 & 0.032 & 0.025 & 0.046 & 0.024 & 0.08 & 0.027 & 0.028 & 0.038 & 0.025 & 0.038 & 0 & 0.026 & 0.129 & 0.033 \\
\hline SE & 032 & 0.025 & 0.022 & 0.045 & 0.021 & 0.143 & 0.022 & 0.029 & 0.028 & 0.023 & 0.029 & 0.115 & 0.022 & 0 & 0.025 \\
\hline UK & 0.025 & 0.077 & 0.035 & 0.03 & 0.033 & 0.025 & 0.076 & 0.022 & 0.075 & 0.025 & 0.07 & 0.031 & 0.032 & 0.027 & \\
\hline
\end{tabular}

\begin{tabular}{|c|c|c|c|c|c|c|c|c|c|c|c|c|c|c|c|}
\hline \multicolumn{16}{|c|}{ Cross-country base elasticities wrt. EATR weighted with the relative distances } \\
\hline$\Lambda \_2=0.425$ & AT & $\mathrm{BE}$ & $\mathrm{CH}$ & $\mathrm{DE}$ & ES & $\mathrm{FI}$ & FR & GR & IE & IT & $\mathrm{NL}$ & $\mathrm{NO}$ & PT & SE & UK \\
\hline AT & $\overline{0}$ & 0.026 & 0.038 & 0.052 & 0.023 & 0.031 & 0.025 & 0.041 & 0.02 & 0.045 & 0.026 & 0.026 & 0.022 & 0.03 & 0.022 \\
\hline $\mathrm{BE}$ & 0.02 & 0 & 0.032 & 0.025 & 0.019 & 0.016 & 0.059 & 0.015 & 0.027 & 0.018 & 0.087 & 0.02 & 0.018 & 0.018 & 0.051 \\
\hline $\mathrm{CH}$ & 0.036 & 0.041 & 0 & 0.03 & 0.03 & 0.02 & 0.048 & 0.026 & & 0. & 0.033 & 0.02 & 0.026 & 0.02 & 0.03 \\
\hline $\mathrm{DE}$ & 0.05 & 0.032 & 0.03 & 0 & 0.019 & 0.035 & 0.025 & 0.025 & 0.023 & & 0.037 & 37 & 0.019 & 0.04 & 0.025 \\
\hline ES & 0.02 & 0.022 & 0.027 & 0.018 & 0 & 0.018 & 0.029 & 0.027 & 0.029 & 0. & 0.02 & 18 & 0.121 & 0.017 & 0.026 \\
\hline $\mathrm{FI}$ & 0.026 & 0.019 & 0.018 & 0.031 & 0.018 & 0 & 0.017 & 0.027 & 0.021 & 22 & 0. & & 0.019 & 14 & 0.019 \\
\hline FR & 0.021 & 0.066 & 0.042 & 0.022 & 0.028 & 0.017 & 0 & 0.018 & 0.031 & 0.022 & & & 0.025 & 0.017 & 0.056 \\
\hline GR & 0.044 & 0.022 & 0.029 & 0.0 & 0. & 0.0 & 0.023 & 0 & 0.022 & 0. & & & 0.033 & 29 & 0.021 \\
\hline IE & 0.02 & 0.035 & 0.024 & 0 & 0. & 0.024 & 0.036 & 0.02 & 0 & 02 & 0. & & 0.034 & 0.025 & 0.064 \\
\hline IT & 0.046 & 0.024 & 0.044 & 0 & 0 . & 0.0 & 0.027 & 0.058 & 0.021 & 0 & 0.022 & & 0. & 0.022 & 0.022 \\
\hline $\mathrm{NL}$ & 0.021 & 0.092 & 0.027 & 0.0 & 0.018 & 0.0 & 0.039 & 0.016 & 3 & 0.018 & 0 & 0.025 & 0.018 & 0.022 & 0.049 \\
\hline NO & 0.023 & 0.023 & 0.018 & 0.033 & 0.018 & 0.058 & 0.02 & 0.021 & 0.028 & 0.018 & 0.028 & 0 & 0.019 & 0.094 & 0.024 \\
\hline SE & 0.023 & 0.018 & 0.016 & 0.033 & 0.015 & 0.104 & 0.016 & 0.021 & 0.02 & 0.0 & 0.021 & & 0.016 & 0 & 0.018 \\
\hline UK & 0.018 & 0.056 & 0.026 & 0.022 & 0.024 & 0.018 & 0.055 & 0.016 & 0.055 & 0.018 & 0.051 & 0.023 & 0.023 & 0.019 & \\
\hline
\end{tabular}

Figure 3: Matrix of CIT base elasticities of the countries (listed on the left) with respect to the CIT rates of all the neighbouring countries (listed above) where neighbourliness is defined according to relative geographic proximity. 


\section{A.2 Descriptive statistics and variable description}

Table 5: Descriptive Statistics

\begin{tabular}{lccccc}
\hline \hline \multicolumn{1}{c}{ Variable } & Mean & Std. Dev. & Min & Max & Obs \\
\hline EATR & 0.281 & 0.086 & 0.05 & 0.479 & 322 \\
Statrate & 0.381 & 0.121 & 0.1 & 0.627 & 322 \\
ln tax base & 1.317 & 0.535 & -0.187 & 2.403 & 322 \\
\hline Energy & 7.502 & 13.070 & 0.11 & 63.9 & 322 \\
Growth & 2.588 & 2.160 & -6.208 & 15.6 & 322 \\
Inflation & 82.813 & 19.748 & 10.91 & 116.06 & 322 \\
ULC & 0.526 & 0.170 & 0.155 & 1.118 & 322 \\
ln GDP & 2.441 & 0.485 & 1.278 & 3.440 & 322 \\
\hline Population & 25650.52 & 24880.32 & 3485.8 & 82534.2 & 322 \\
Unemployment & 7.718 & 4.002 & 0.4 & 19.5 & 322 \\
\hline
\end{tabular}

Table 6: Correlation matrix for the tax base equation with $\omega_{i j}^{\text {dist }}$ and EATR

\begin{tabular}{lcccccc}
\hline \hline & $\ln \tau_{i t-1}$ & $\ln \bar{\tau}_{i t-1}$ & Growth $_{i t}$ & $\ln$ GDP $_{i t-1}$ & ULC $_{i t-1}$ & Energy $_{i t}$ \\
\hline $\ln \tau_{i t-1}$ & 1.00 & & & & & \\
$\ln \bar{\tau}_{i t-1}$ & 0.19 & 1.00 & & & & \\
Growth $_{i t}$ & -0.35 & 0.02 & 1.00 & & & \\
$\operatorname{ln~GDP~}_{i t-1}$ & 0.36 & -0.43 & -0.17 & 1.00 & & \\
ULC $_{i t-1}$ & 0.10 & -0.14 & -0.20 & 0.19 & 1.00 & \\
Energy $_{i t}$ & 0.12 & 0.00 & 0.04 & -0.20 & -0.07 & 1.00 \\
Inflation $_{i t}$ & -0.24 & -0.85 & 0.09 & 0.38 & 0.33 & -0.08 \\
\hline
\end{tabular}


Table 7: Variable description

\begin{tabular}{|c|c|c|}
\hline Variable & Measure & Source \\
\hline EATR & $\begin{array}{l}\text { Effective average tax rate on corporate } \\
\text { profits }\end{array}$ & $\begin{array}{l}\text { Devereux and Griffith } \\
(2003)\end{array}$ \\
\hline Statrate & Statutory tax rate on corporate profit & $\begin{array}{l}\text { Devereux and Griffith } \\
(2003)\end{array}$ \\
\hline ln tax base & $\begin{array}{l}\text { CIT revenues in bn US dollars divided } \\
\text { by the statutory tax rate, expressed in } \\
\text { logarithm }\end{array}$ & $\begin{array}{l}\text { OECD Revenue online } \\
\text { database }\end{array}$ \\
\hline Total tax rev & Total tax revenues in bn US dollars & $\begin{array}{l}\text { OECD Revenue online } \\
\text { database }\end{array}$ \\
\hline Energy & $\begin{array}{l}\text { Fuel exports in percent of merchandise } \\
\text { exports }\end{array}$ & WDI \\
\hline Growth & $\begin{array}{l}\text { Percentage change in real GDP over } \\
\text { previous year }\end{array}$ & $\begin{array}{l}\text { International Monetary } \\
\text { Fund (IMF) }\end{array}$ \\
\hline Inflation & Consumer price index $(2000=100)$ & WDI \\
\hline ULC & $\begin{array}{l}\text { Unit labour costs measured as com- } \\
\text { pensation of employees in US dollars } \\
\text { (at market exchange rates) divided by } \\
\text { nominal GDP in US dollars (in PPP) }\end{array}$ & OECD National Accounts \\
\hline $\ln$ GDP & $\begin{array}{l}\text { Gross domestic product in bn US Dol- } \\
\text { lars at market exchange rates in loga- } \\
\text { rithm }\end{array}$ & IMF \\
\hline Population & Population in thousands of inhabitants & Ameco online database \\
\hline Unemployment & $\begin{array}{l}\text { Total unemployment rate (definition } \\
\text { EUROSTAT) }\end{array}$ & Ameco online database \\
\hline dist & $\begin{array}{l}\text { distances between the capitals in kilo- } \\
\text { meters measured upon the data on lat- } \\
\text { itudes and longitudes }\end{array}$ & www.fallingrain.com/world \\
\hline
\end{tabular}




\section{References}

Altshuler, R., Goodspeed T.J., 2002. Follow the Leader? Evidence on European and U.S. Tax Competition. Rutgers University, Departmental Working Paper No. 200226.

Anselin, L., 1988. Spatial Econometrics. Methods and Models. Kluwer, Dordrecht.

Baltagi, B.H., 2005. Econometric Analysis of Panel Data. John Wiley and Sons Ltd, England.

Bartelsman, E.J., Beetsma, R.M.W.J., 2003. Why pay more? Corporate tax avoidance through transfer pricing in OECD Countries. Journal of Public Economics 87(9-10), pp. 2225-2252.

Beck, N., Katz, J.N., 1995. What to do (and not to do) with Time-Series Cross-Section Data. The American Political Science Review 89(3), pp. 634-647.

Besley, T., Case, A., 1995. Incumbent behavior: Vote seeking, tax setting and yardstick competition. American Economic Review 85, pp. 25-45.

Brett, C., Pinkse, J., 2000. The determinants of municipal tax rates in British Columbia. Canadian Journal of Economics 33(3), pp. 695-714. 2000.

Brett, C., Tardif, C. 2006. The Grants are Falling! The Grants are Falling! Municipal Government Response to Changes in Provincial Support in New Brunswick, 1983-2003. Mount Allison University Working Paper, Department of Economics.

Brueckner, J.K., 2003. Strategic Interaction Among Governments: An Overview of Empirical Studies. International Regional Science Review 26, pp. 175188.

Bucovetsky, S., 1991. Asymmetric tax competition. Journal of Urban Economics 30, pp. 167-181.

Buettner, T., 2001. Local business taxation and competition for capital: the choice of the tax rate. Regional Science and Urban Economics 31, pp. $215-245$.

Buettner, T., 2003. Tax base effects and fiscal externalities of local capital taxation: evidence from a panel of German jurisdictions. Journal of Urban Economics 54, pp. 110-128.

Case, A.C., Rosen, H.S., Hines, Jr.J.R. 1993. Budget spillovers and fiscal policy interdependence. Journal of Public Economics 52, pp. 285-307.

Clausing, K.A., 2003. Tax motivated transfer pricing and US intra-firm trade prices. Journal of Public Economics 87, pp. 2207-2223. 
Clausing, K.A., 2007. Corporate Tax Revenues in OECD Countries. International Tax and Public Finance 14, pp. 115-33.

Daveri, F., Tabellini, G., 2000. Unemployment, growth and taxation in industrialised countries. Economic Policy 15(30), pp. 47-104.

Desai, M.P., Dharmapala, D., 2007. Taxes, institutions and foreign diversification opportunities. NBER Working Paper 13132.

Desai, M.P., Foley, C.F., Hines, J.R., 2006. The demand for tax haven operations. Journal of Public Economics 90, pp. 513-531.

Devereux, M.P., Griffith, R., 1998. The Taxation of Discrete Investment Choices. Keele Department of Economics Discussion Papers (1995-2001) 98/08.

Devereux, M.P., Griffith, R., 2003. Evaluating Tax Policy for Location Decisions. International Tax and Public Finance 10(2), pp. 107-26.

Devereux, M.P., Griffith, R., Klemm, A., 2002b. Corporate income tax reforms and international tax competition. Economic Policy 35, pp. 451-495.

Devereux, M.P., Lockwood, B., Redoano, M., 2002a. Do Countries Compete over Corporate Tax Rates? CEPR Discussion Papers 3400.

Devereux, M.P., 2007. Developments in the Taxation of Corporate Profit in the OECD Since 1965: Rates, Bases and Revenues. Working Papers 0704, Oxford University Centre for Business Taxation.

Eurostat. 2005. Structures of the taxation systems in the European Union. Luxembourg: Office for Official Publications of the European Communities.

Faggio, G., Nickell, S., 2007. Patterns of Work Across the OECD. The Economic Journal 117, pp. 416-440.

Griffith, R., Klemm, A., 2004. What has been the tax competition experience of the past 20 years? Institute for Fiscal Studies (IFS) Working Papers W04/05.

Gujarati, D., 2003. Basic Econometrics. McGraw-Hill, New York.

Hines, J.R., 1999. Lessons from Behavioral Responses to International Taxation, National Tax Journal, June, pp. 305-322.

Huizinga, H.P., Laeven, L., 2007. International Profit Shifting within European Multinationals. CEPR Discussion Papers No. 6048.

Kelejian, H.H., Kapoor, M., Prucha, I.R., 2007. Panel Data Models with Spatially Correlated Error Components. Journal of Econometrics 140, pp. 97-130. 
Kelejian, H.H., Prucha, I.R., 1998. A Generalized Spatial Two-Stage Least Squares Procedures for Estimating a Spatial Autoregressive Model with Autoregressive Disturbances. Journal of Real Estate Finance and Economics 17, pp. 99-121.

Kelejian, H.H., Prucha, I.R., 1999. A Generalized Moments Estimator for the Autoregressive Parameter in a Spatial Model. International Economic Review 40(2), p. 509-533.

Kelejian, H.H., Prucha, I.R., 2006. Specification and Estimation of Spatial Autoregressive Models with Autoregressive and Heteroscedastic Disturbances. Department of Economics, University of Maryland.

Kmenta, J., 2003. Elements of Econometrics (second edition, 4th print). MacMillan Publishing Company, New York.

Parks, R., 1967. Efficient Estimation of a system of Regression Equations When Disturbances Are Both Serially and Contemporaneously Correlated. Journal of the American Statistical Association 62, pp. 500-509.

Redoano, M., 2007. Fiscal interactions among European countries. Does the EU matter? CESIFO Working Paper No. 1952.

Revelli, F., 2005. On Spatial Public Finance Empirics. International Tax and Public Finance 12, pp. 475-492.

Rodrick, D., 1997. Has globalization gone too far? Institute for International Economics, Washington DC.

Stock, J.H., Yogo, M., 2002. Testing for weak instruments in linear IV regression. NBER Technical Working Paper N0.284.

Venables, A.J., Rice, P.G., Stewart, M., 2003. The Geography of IntraIndustry Trade: Empirics. Topics in Economic Analysis \& Policy 3(1).

Verbeek, M., 2004. A Guide to Modern Econometrics. John Wiley \& Sons, England.

Weichenrieder, A.J., 2007. Profit Shifting in the EU: Evidence from Germany. CESifo Working Paper No. 2043.

Wilson, J.D., 1986. A Theory of Interregional Tax Competition. Journal of Urban Economics 19(3), pp. 296-315.

Wilson, J.D., 1991. Tax competition with interregional differences in factor endowments. Regional Science and Urban Economics 21(3), pp. 423-451.

Wooldridge, J.M., 2003. Introductory Economics (2nd edition). Thomson, South Western: Mason Ohio. 
Zodrow, G.R., 2003. Tax Competition and Tax Coordination in the European Union. International Tax and Public Finance 10, pp. 651-671.

Zodrow, G.R., Mieszkowski, P., 1986. Pigou, Tiebout, Property Taxation and the Underprovision of Local Public Goods. Journal of Urban Economics 19, pp. 356-370. 


\section{Index of Working Papers:}

\begin{tabular}{|c|c|c|c|}
\hline $\begin{array}{l}\text { January } 4, \\
2006\end{array}$ & $\begin{array}{l}\text { Ignacio Briones, } \\
\text { André Villela } \\
\text { (comments by Forrest } \\
\text { Capie and Patrick } \\
\text { Honohan) }\end{array}$ & 108 & $\begin{array}{l}\text { European Banks and their Impact on the } \\
\text { Banking Industry in Chile and Brazil: } 1862 \text { - } \\
1913\end{array}$ \\
\hline $\begin{array}{l}\text { January 5, } \\
2006\end{array}$ & $\begin{array}{l}\text { Jérôme Sgard } \\
\text { (comment by Yishay } \\
\text { Yafeh) }\end{array}$ & 109 & $\begin{array}{l}\text { Bankruptcy Law, Creditors' Rights and } \\
\text { Contractual Exchange in Europe, 1808-1914 }\end{array}$ \\
\hline $\begin{array}{l}\text { January } 9 \\
2006\end{array}$ & $\begin{array}{l}\text { Evelyn Hayden, } \\
\text { Daniel Porath, } \\
\text { Natalja von } \\
\text { Westernhagen }\end{array}$ & 110 & $\begin{array}{l}\text { Does Diversification Improve the } \\
\text { Performance of German Banks? Evidence } \\
\text { from Individual Bank Loan Portfolios }\end{array}$ \\
\hline $\begin{array}{l}\text { January 13, } \\
2006\end{array}$ & $\begin{array}{l}\text { Markus Baltzer } \\
\text { (comments by Luis } \\
\text { Catão and Isabel } \\
\text { Schnabel) }\end{array}$ & 111 & $\begin{array}{l}\text { European Financial Market Integration in the } \\
\text { Gründerboom and Gründerkrach: Evidence } \\
\text { from European Cross-Listings }\end{array}$ \\
\hline $\begin{array}{l}\text { January } 18, \\
2006\end{array}$ & $\begin{array}{l}\text { Michele Fratianni, } \\
\text { Franco Spinelli } \\
\text { (comments by John } \\
\text { Driffill and Nathan } \\
\text { Sussman) }\end{array}$ & 112 & $\begin{array}{l}\text { Did Genoa and Venice Kick a Financial } \\
\text { Revolution in the Quattrocento? }\end{array}$ \\
\hline $\begin{array}{l}\text { January 23, } \\
2006\end{array}$ & $\begin{array}{l}\text { James Foreman-Peck } \\
\text { (comment by Ivo Maes) }\end{array}$ & 113 & Lessons from Italian Monetary Unification \\
\hline $\begin{array}{l}\text { February 9, } \\
2006\end{array}$ & $\begin{array}{l}\text { Stefano Battilossi } \\
\text { (comments by Patrick } \\
\text { McGuire and Aurel } \\
\text { Schubert) }\end{array}$ & 114 & $\begin{array}{l}\text { The Determinants of Multinational Banking } \\
\text { during the First Globalization, } 1870-1914\end{array}$ \\
\hline $\begin{array}{l}\text { February 13, } \\
2006\end{array}$ & Larry Neal & 115 & $\begin{array}{l}\text { The London Stock Exchange in the 19th } \\
\text { Century: Ownership Structures, Growth and } \\
\text { Performance }\end{array}$ \\
\hline March 14, 2006 & $\begin{array}{l}\text { Sylvia Kaufmann, } \\
\text { Johann Scharler }\end{array}$ & 116 & $\begin{array}{l}\text { Financial Systems and the Cost Channel } \\
\text { Transmission of Monetary Policy Shocks }\end{array}$ \\
\hline March 17, 2006 & Johann Scharler & 117 & $\begin{array}{l}\text { Do Bank-Based Financial Systems Reduce } \\
\text { Macroeconomic Volatility by Smoothing } \\
\text { Interest Rates? }\end{array}$ \\
\hline
\end{tabular}




\begin{tabular}{|c|c|c|c|}
\hline March 20, 2006 & $\begin{array}{l}\text { Claudia Kwapil, } \\
\text { Johann Scharler }\end{array}$ & 118 & $\begin{array}{l}\text { Interest Rate Pass-Through, Monetary } \\
\text { Policy Rules and Macroeconomic Stability }\end{array}$ \\
\hline March 24, 2006 & $\begin{array}{l}\text { Gerhard Fenz, } \\
\text { Martin Spitzer }\end{array}$ & 119 & $\begin{array}{l}\text { An Unobserved Components Model to } \\
\text { forecast Austrian GDP }\end{array}$ \\
\hline April 28, 2006 & $\begin{array}{l}\text { Otmar Issing } \\
\text { (comments by Mario } \\
\text { Blejer and Leslie } \\
\text { Lipschitz) }\end{array}$ & 120 & Europe's Hard Fix: The Euro Area \\
\hline May 2, 2006 & $\begin{array}{l}\text { Sven Arndt } \\
\text { (comments by Steve } \\
\text { Kamin and Pierre } \\
\text { Siklos) }\end{array}$ & 121 & $\begin{array}{l}\text { Regional Currency Arrangements in North } \\
\text { America }\end{array}$ \\
\hline May 5, 2006 & $\begin{array}{l}\text { Hans Genberg } \\
\text { (comments by Jim Dorn } \\
\text { and Eiji Ogawa) }\end{array}$ & 122 & $\begin{array}{l}\text { Exchange-Rate Arrangements and Financial } \\
\text { Integration in East Asia: On a Collision } \\
\text { Course? }\end{array}$ \\
\hline May 15,2006 & Petra Geraats & 123 & The Mystique of Central Bank Speak \\
\hline May 17,2006 & Marek Jarociński & 124 & $\begin{array}{l}\text { Responses to Monetary Policy Shocks in the } \\
\text { East and the West of Europe: A Comparison }\end{array}$ \\
\hline June 1, 2006 & $\begin{array}{l}\text { Josef Christl } \\
\text { (comment by Lars } \\
\text { Jonung and concluding } \\
\text { remarks by Eduard } \\
\text { Hochreiter and George } \\
\text { Tavlas) }\end{array}$ & 125 & $\begin{array}{l}\text { Regional Currency Arrangements: Insights } \\
\text { from Europe }\end{array}$ \\
\hline June 5, 2006 & $\begin{array}{l}\text { Sebastian Edwards } \\
\text { (comment by Enrique } \\
\text { Alberola) }\end{array}$ & 126 & $\begin{array}{l}\text { Monetary Unions, External Shocks and } \\
\text { Economic Performance }\end{array}$ \\
\hline \multirow[t]{3}{*}{ June 9, 2006} & Richard Cooper & 127 & $\begin{array}{l}\text { Proposal for a Common Currency among } \\
\text { Rich Democracies }\end{array}$ \\
\hline & $\begin{array}{l}\text { Michael Bordo and } \\
\text { Harold James }\end{array}$ & & One World Money, Then and Now \\
\hline & $\begin{array}{l}\text { (comment on both } \\
\text { papers by Sergio } \\
\text { Schmukler) }\end{array}$ & & \\
\hline June 19,2006 & David Laidler & 128 & $\begin{array}{l}\text { Three Lectures on Monetary Theory and } \\
\text { Policy: Speaking Notes and Background } \\
\text { Papers }\end{array}$ \\
\hline
\end{tabular}




\begin{tabular}{|c|c|c|c|}
\hline July 9,2006 & $\begin{array}{l}\text { Ansgar Belke, } \\
\text { Bernhard Herz, } \\
\text { Lukas Vogel }\end{array}$ & 129 & $\begin{array}{l}\text { Are Monetary Rules and Reforms } \\
\text { Complements or Substitutes? A Panel } \\
\text { Analysis for the World versus OECD } \\
\text { Countries }\end{array}$ \\
\hline August 31, 2006 & $\begin{array}{l}\text { John Williamson } \\
\text { (comment by Marc } \\
\text { Flandreau) }\end{array}$ & 130 & A Worldwide System of Reference Rates \\
\hline $\begin{array}{l}\text { September 15, } \\
2006\end{array}$ & $\begin{array}{l}\text { Sylvia Kaufmann, } \\
\text { Peter Kugler }\end{array}$ & 131 & $\begin{array}{l}\text { Expected Money Growth, Markov Trends } \\
\text { and the Instability of Money Demand in the } \\
\text { Euro Area }\end{array}$ \\
\hline $\begin{array}{l}\text { September 18, } \\
2006\end{array}$ & $\begin{array}{l}\text { Martin Schneider, } \\
\text { Markus Leibrecht }\end{array}$ & 132 & $\begin{array}{l}\text { AQM-06: The Macroeconomic Model of the } \\
\text { OeNB }\end{array}$ \\
\hline $\begin{array}{l}\text { November 6, } \\
2006\end{array}$ & $\begin{array}{l}\text { Erwin Jericha and } \\
\text { Martin Schürz }\end{array}$ & 133 & A Deliberative Independent Central Bank \\
\hline $\begin{array}{l}\text { December 22, } \\
2006\end{array}$ & Balázs Égert & 134 & $\begin{array}{l}\text { Central Bank Interventions, Communication } \\
\text { and Interest Rate Policy in Emerging } \\
\text { European Economies }\end{array}$ \\
\hline May 8,2007 & Harald Badinger & 135 & $\begin{array}{l}\text { Has the EU's Single Market Programme } \\
\text { fostered competition? Testing for a decrease } \\
\text { in markup ratios in EU industries }\end{array}$ \\
\hline May 10,2007 & Gert Peersman & 136 & $\begin{array}{l}\text { The Relative Importance of Symmetric and } \\
\text { Asymmetric Shocks: the Case of United } \\
\text { Kingdom and Euro Area }\end{array}$ \\
\hline May 14,2007 & $\begin{array}{l}\text { Gerhard Fenz and } \\
\text { Martin Schneider }\end{array}$ & 137 & $\begin{array}{l}\text { Transmission of business cycle shocks } \\
\text { between unequal neighbours: Germany and } \\
\text { Austria }\end{array}$ \\
\hline July 5, 2007 & Balázs Égert & 138 & $\begin{array}{l}\text { Real Convergence, Price Level } \\
\text { Convergence and Inflation Differentials in } \\
\text { Europe }\end{array}$ \\
\hline $\begin{array}{l}\text { January } 29, \\
2008\end{array}$ & $\begin{array}{l}\text { Michał Brzoza- } \\
\text { Brzezina, } \\
\text { Jesus Crespo } \\
\text { Cuaresma }\end{array}$ & 139 & $\begin{array}{l}\text { Mr. Wicksell and the global economy: } \\
\text { What drives real interest rates? }\end{array}$ \\
\hline March 6, 2008 & Helmut Stix & 140 & $\begin{array}{l}\text { Euroization: What Factors drive its } \\
\text { Persistence? } \\
\text { Household Data Evidence for Croatia, } \\
\text { Slovenia and Slovakia }\end{array}$ \\
\hline
\end{tabular}


April 28, $2008 \quad$ Kerstin Gerling

141 The Real Consequences of Financial Market Integration when Countries Are

Heterogeneous

April 29, $2008 \quad$ Aleksandra Riedl and

Silvia Rocha-Akis

142 Testing the tax competition theory:

How elastic are national tax bases in

Western Europe? 